\title{
Editorial
}

\section{The Paschal Mystery and the Church}

\author{
Paul Avis \\ Editor-in-Chief of Ecclesiology; Honorary Professor, Department \\ of Theology and Religion, Durham University, Durham, UK \\ Editor-in-Chief of Ecclesiology; Honorary Research Fellow, Department \\ of Theology and Religion, University of Exeter, Exeter, UK \\ dr.paul.avis@gmail.com
}

If we were to ask, 'What is ecclesiology all about?', I think the answer would have to be that ecclesiology is essentially about the connection between Jesus Christ and the church. There are many fascinating scholarly avenues to be explored in relation to the Christian church: its history, theology, ministry, missions, worship, pastoral practices, councils, polities, art, music, sociology, and so on. But we should never forget that this elaborate ecclesiological superstructure ultimately depends on establishing a valid connection between the church and Jesus. Otherwise it would be all a huge human invention, while blasphemously claiming divine sanction and authority. But the relationship or connection between the church and Jesus should not be taken for granted, but should be approached as an entirely open theological question, as is appropriate in any critical Fundamental Ecclesiology. I began to open up this question in my Editorial 'Jesus and the Church' in this Journal just over a year ago (15.3, 2019, pp. 255-260) and I hope to take the enquiry a step further now.

During the past two thousand years, the church has claimed the direct authority of Christ for many teachings, dogmas, political structures, moral instructions and other ecclesial practices, alleging that Christ wills them or that the New Testament mandates them. But other Christian groups have 
vigorously challenged many such claims and have substituted equally tendentious claims of their own, ironically appealing to the same dominical or at least apostolic authority. However, modern historical-critical study of Christian origins has rendered most such attempts to validate these oppositional confessional stances by direct reference to Christ's institution untenable.

The ultimate ecclesiological question concerning Jesus and the church may be approached in various ways, but two particular pathways stand out: the mainly historical and the mainly theological. Of course, they cannot be kept entirely apart, but they can be distinguished methodologically. The historical question is to ask whether Jesus of Nazareth founded the church, with its ministerial and sacramental structure, as an intentional act, as is still claimed in the official theology of certain churches. Here there is an attempt to validate the hierarchical structure of the historical and present-day institution by an appeal to an act of Jesus in his earthly ministry. However, biblical and patristic scholarship during the past two centuries has called this purportedly historical claim seriously into question on several grounds which can be briefly summarised. (a) It is clear from the Gospels that Jesus' mission was almost entirely to 'the lost sheep of the house of Israel' (Matt. 10:6; 15:24), with a call to repentance and to faith in the good news of the reign of God that was at hand in his person and ministry (Mark 1:14-15). His message was intended for the already existing Jewish church - a political theocracy, yes, but certainly also and as such a church, the assembly which understood itself to have been called together by Yahweh for true worship (it is often termed the ekklesia in the LXX). Jesus did not need to found a church - Jesus could not found a church - because the church of God already existed. Jesus and the apostles belonged to it and ministered within it. The alternative to accepting this picture of Jesus-already-within-the-church is to posit that a (putative) church founded by Christ was intended by him to replace and supersede the Jewish church (a position known as supercessionism) and to hold as a concomitant that God had at that point rejected God's covenant people - a view which St Paul explicitly condemns in Romans 11:1. (b) The New Testament and early Christian documents show little evidence of any institutional structure of the community. Paul's early epistles reflect a basically charismatic situation in which individuals were guided by the Holy Spirit to exercise Spiritgiven gifts (1 Cor. 12 and 14; Rom. 12:3-8). Even in the Pastoral Epistles, where Paul (or 'Paul') is making provision for orderly oversight and management of the community, the structures are embryonic and pragmatic, hardly the Urkatholizismus that some have detected in these letters. Alongside the lack of evidence of any settled institutional structure for the early Christian communities, we have to set the fact of the wide diversity of belief, canon, worship 
and organisation across the churches of the Roman Empire, a diversity that lasted for several centuries. There was no single template of faith and order. The evidence of the first-century church tells strongly against the claim that Jesus instituted a formal pattern for his followers to adhere to. (c) In many places the New Testament writings testify to an imminent expectation of the parousia on the part of the community, the apostles and Jesus himself. It speaks of the manifestation of the kingdom, the return of the Son of Man, the judgement, the resurrection. The impending eschatological denouement is abundantly evident on the surface of the text, in the Gospels, the Epistles, the Acts of the Apostles and the Apocalypse, for all who read with their eyes open. The foreshortened timetable of New Testament eschatology also seems to rule out a specific founding of the church, set up for the long haul, by Jesus Christ.

However, the conclusion that Jesus of Nazareth did not found or institute a church in any form that was intended to be permanent, does not mean that he did not have intentions for his band of disciples in the limited time that was expected to be available before the parousia. The eschatological horizon in the thought-world of that time required that there should be an eschatological community of the last days. This community was the remnant, foretold by the Hebrew prophets, that would remain faithful to the reign of God and would in the end be vindicated by God. But the conclusion that Jesus did not found or institute a church in any enduring form does have several critical implications. Here we move from mainly historical to mainly theological considerations, from 'Did Jesus Christ found the church?' to 'How is the church founded upon Jesus Christ?'

(a) It is not plausible to claim dominical institution for any particular ecclesiastical polity or form of ministry or structure of authority. Such claims have never been purely historical; they have always been tainted by ideology, made to serve certain power functions and to protect the privileges of a few. Of course, arguments can be put forward for particular forms of ministry and authority on other grounds, especially tradition, ecumenism, or pastoral effectiveness. But any such claims cannot be absolutized. They cannot be made to serve the unchurching by one Christian body of other Christian bodies that has disfigured Christian history; all such anathemas are baseless.

(b) The failures and sins (of which we are acutely conscious at the present time) of the institutional church cannot be traced back to the way that Jesus set up the church; they cannot be laid at his door. Jesus and his gospel are not discredited when the church fails. If we believed, on good grounds, that Jesus foresaw or intended the church of history and the 
church of today, which falls abysmally short of the level of its 'founder', we would be tempted to conclude that Jesus had failed disastrously in his purpose. But Jesus did not 'design' the church, so he cannot be blamed for what has gone wrong with it. Jesus did not plan a church that, alongside all that is 'worthy' of him (the preaching of 'good news', the offering of pure worship, compassionate ministry to the poor, and many examples of outstanding sanctity), is also broken into fragments, riddled with conflict, colludes with powerful and corrupt interests, and commits sins and crimes in its own right. ${ }^{1}$

(c) Without empirical institutional continuity with the mission of Jesus of Nazareth, on what basis should we proceed ecclesiologically? How do we remain in tune with the mind of Christ (1 Cor. 2:16)? The church is called to be conformed, not to some dominical blueprint with inevitable political and legal connotations, but to the person and work and character of Christ, to the gospel (cf. Rom. 12:2). The Paschal Mystery of the reconciling passion, death, resurrection and ascension of the incarnate Son of God and the outpouring of the Holy Spirit is the event that launched the Christian community. The Paschal Mystery includes and contains the church. It is commemorated, participated in and received daily in the celebration of the Eucharist. So the Paschal Mystery includes and contains the Eucharist. The Eucharist generates a dynamic of continual conversion to Christ and to the body of Christ. The dynamic of continual conversion to Christ is worked out ecclesiologically in the momentum of ongoing reform, guided by biblical axioms, ethical criteria and consecrated reason. Missiological adaptation of the institution is a proper function of the church. So flexibility of practice is permitted and development in faith and order is mandated. ${ }^{2}$

1 See further, my 'Overcoming "The Church as Counter-Sign of the Kingdom”, in Mark D. Chapman and Vladimir Latinovic (eds), Changing the Church: Transformations of Christian Belief, Practice, and Life (Cham, Switzerland: Palgrave Macmillan, 2021), pp. 243-249.

2 There is a fuller discussion of these questions in my Jesus and the Church:The Foundation of the Church in the New Testament and Modern Theology (T\&T Clark, 2020). 